\title{
Risky road-use behaviour among students at the University of Benha, Egypt
}

\author{
S.D. El-Gendy, M.F. El-Gendy, ${ }^{7}$ A.Y. Dawah, ${ }^{1}$ R.S. Eldesouky ${ }^{7}$ and M.S. Abd El-Raof ${ }^{1}$
}

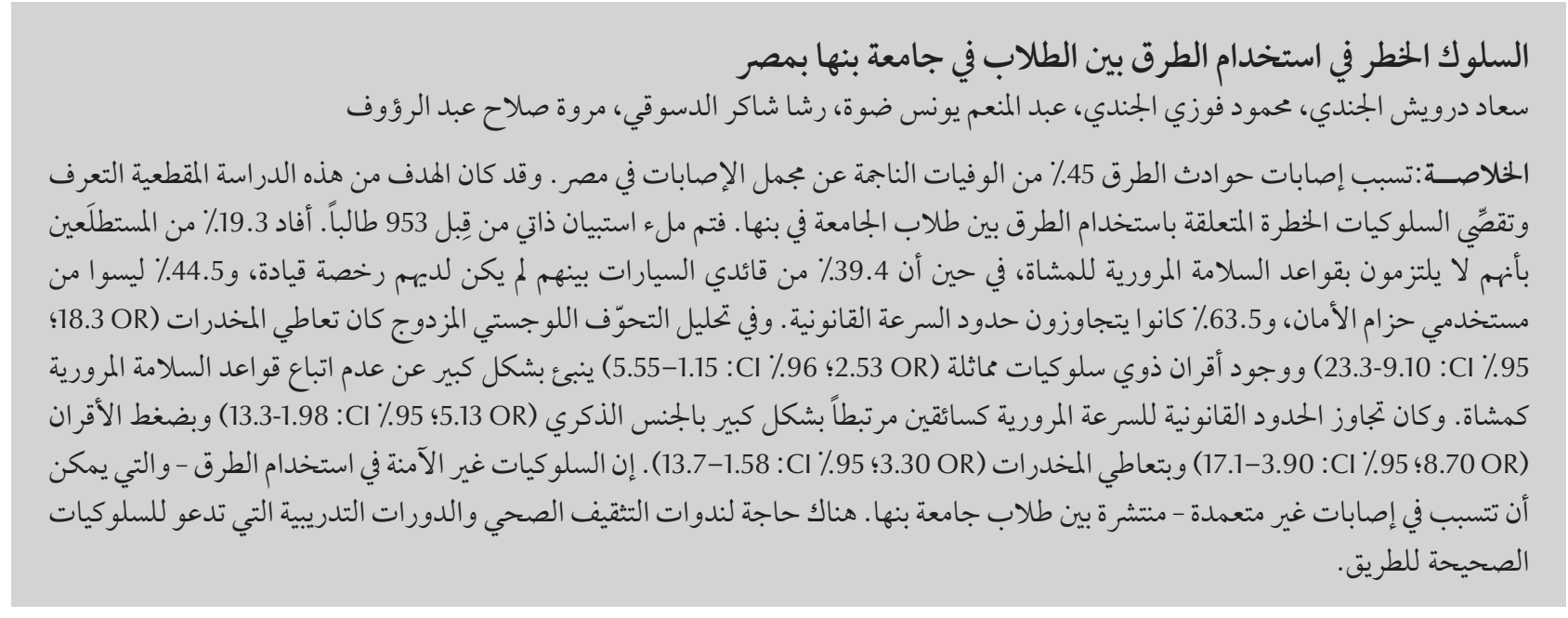

ABSTRACT Road traffic injuries constitute 45\% of deaths due to injury in Egypt. The aim of this cross-sectional study was to identify and investigate risky behaviours regarding road use among university students in Benha. A self-administered questionnaire was completed by 953 students. Of the respondents 19.3\% reported not complying with pedestrian road traffic safety rules, while among drivers, 39.4\% had no driving licence, $44.5 \%$ did not use a seat-belt and $63.5 \%$ exceeded the legal speed limits. In binary logistic regression analysis, substance use (OR 18.3; 95\% Cl: 9.10-23.3) and having peers with similar behaviours (OR 2.53; 96\% Cl: 1.15-5.55) were significant predictors of not following road traffic safety rules as a pedestrian. Exceeding the legal traffic speed limits as a driver was significantly associated with male sex (OR 5.13; 95\% Cl: 1.98-13.3), peer pressure (OR 8.70; 95\% Cl: 3.90-17.1) and substance use (OR 3.30; 95\% Cl: 1.58-13.7). Unsafe road-use behaviours that may cause unintentional injuries are prevalent among University of Benha students. Health education sessions and training courses for students on appropriate road behaviours may be warranted.

\section{Comportement routier à risque chez des étudiants de l'Université de Benha (Égypte)}

RÉSUMÉ Les traumatismes dus aux accidents de la circulation sont responsables de $45 \%$ des décès causés par des traumatismes en Égypte. L'objectif de la présente étude transversale était d'identifier et d'analyser les comportements à risque sur la route chez des étudiants de l'Université de Benha. Un autoquestionnaire a été rempli par 953 étudiants. Parmi les répondants, 19,3\% ont déclaré ne pas respecter les règles de sécurité de la circulation routière pour les piétons, tandis que $39,4 \%$ des conducteurs n'étaient pas titulaires d'un permis de conduire; $44,5 \%$ ne portaient pas leur ceinture de sécurité et $63,5 \%$ ne respectaient pas les limitations de vitesse légales. À l'analyse de régression logistique binaire, consommer des substances psychoactives (OR 18,3 ; IC à $95 \%$ : 9,10-23,3) et avoir des pairs adoptant des comportements similaires (OR 2,53 ; IC à $96 \%$ : 1,15-5,55) étaient des facteurs prédictifs importants de non-respect des règles de sécurité routière en tant que piéton. Le dépassement de la vitesse autorisée par le conducteur était fortement associé au sexe masculin (OR 5,13 ; IC à 95 \% : 1,98-13,3), à la pression exercée par des pairs (OR 8,70; IC à $95 \%$ : 3,90-17,1) et à l'usage de substances psychoactives (OR 3,30 ; IC à 95 \% : 1,58-13,7). Les comportements à risque des usagers de la route susceptibles de causer des traumatismes non intentionnels sont répandus chez les étudiants de l'Unitversité de Benha. Des cours de formation et des séances d'éducation sanitaire destinés aux étudiants et consacrés aux comportements adéquats sur la route pourraient être justifiés. 


\section{Introduction}

Nearly 1 in 5 people living in the WHO Eastern Mediterranean Region are between the ages of 15 and 24 years. This is a period of transition from the dependence of childhood to the independence of adulthood and is a period during which a number of social, economic, biological and demographic events occur. As the average number of years spent in education increases and marriage is delayed, the transition to adulthood extends over a longer period of time, making adolescence an increasingly important stage for attention by policy-makers (1). This period is characterized by high-risk behaviours that can have adverse effects on the overall development and well-being of youth, or that might prevent them from future success and development (2). Risky behaviour concerning road use is among the most important youthrelated high-risk behaviour.

Road traffic injuries cause an estimated 700 deaths among young people every day (3) and constitute $45 \%$ of mortalities due to injuries in Egypt. Three-quarters $(75 \%)$ of these injuries are pedestrian-related (4). Traffic-related injuries also include those sustained while walking, riding a bicycle or riding a motorcycle (5). Traditionally, research on road traffic injuries has focused on the traffic environment and the vehicles (6). Little attention has been given to risky behaviours towards road use and road safety among pedestrians (7).

Although college students engage in behaviours that threaten both their current and future health, and almost all these risky behaviours are preventable (8), data on road-risk behaviours among university students in Egypt are lacking. It is necessary to collect baseline information about the magnitude of the problem so that intervention programmes can be planned and targeted on those students to raise their awareness towards risky behaviours (9). The objectives of this study were to identify and measure the prevalence of some road traffic risky behaviours among University of Benha students and to investigate some of the factors underlying these behaviours.

\section{Methods}

This cross-sectional study was carried out among University of Benha students. The fieldwork was conducted during the 2 nd term of the academic year 2011-2012.

\section{Sampling}

Multistage, stratified sampling was used to select the participants. Initially 3 colleges - 2 practical-based (Faculty of Medicine and Faculty of Science) and 1 theoretical-based (Faculty of Commerce) - were chosen by simple random sampling from among 15 colleges in the University of Benha. Each college's population was divided into strata (grades) and then 1 section from each grade was chosen by simple random sampling, except for the 4th grade of the Faculty of Commerce for which a speciality was chosen because the population in this grade presented as specialities not sections.

A questionnaire was distributed to 1121 students (672 from the practical-based colleges and 449 from the theoretical-based one) and completed by 953 (a response rate of $85 \%$ ).

\section{Data collection}

A structured, self-administered, anonymous questionnaire in Arabic language was used to collect the data. The questionnaire was adopted and modified from a previously designed questionnaire (10) and was revised by 3 academic professors to assess its content and construct validity. The questionnaire included items about the students' personal and sociodemographic data, relationship with their parents (defined as bad if characterized by tension, arguments all the time and/ or no discussions), relationships with friends (defined as bad if characterized by tension and/or violence, either verbal or physical) and religious commitment (regular attendance at the mosque or church to pray). The questionnaire asked about road use behaviours as a pedestrian (following the pedestrian road safety rules, and substance use) and as a driver (possession of a driver's licence, using a seat-belt, obeying the speed limits on roads, and using alcohol while driving). The questionnaire also included a question about having suffered any pedestrian road accident injury in the previous 6 months.

The students' compliance with pedestrian road safety rules was evaluated by 4 items: looking both ways before crossing the road, waiting for the green traffic signal before crossing the road, walking in the road, and walking down an unsafe sidewalk. The participants indicated the frequency of performing these behaviours on a 5-point Likert scale ranging from 1 ("never") to 5 ("always") (11). These responses were then grouped and analysed dichotomously as "always" for road crossing and "never" for road walking behaviours, versus all other responses. We defined safe behaviour on the roads as always looking both ways or always waiting for a green traffic signal before crossing the road, and as never walking in the road (4). Then a summary score was calculated for this variable, with 1 point awarded for each of the 4 risk behaviours (not always looking both ways before crossing the street; not always waiting for green signal to cross; ever walking in the road; ever walking on an unsafe). Scores from 1 to 4 indicated unsafe behaviour and were considered "not following the road safety rules", while a score of 0 indicated "following the road safety rules".

Students who were drivers were asked about using a seat-belt while driving, obeying the legal traffic speed limit, and substance/alcohol use while driving. This was evaluated in the same manner, using "never" as safe behaviour 
for substance and alcohol abuse and "always" for seat-belt use and obeying the legal speed. Possessing a driver's licence was evaluated as "yes/no". To enhance the accuracy of answers about the items on substance and alcohol use, the questionnaire was completed anonymously and the students were assured that all data would be treated in confidence.

The applicability, content and face validity of the questionnaire were tested through a pilot study carried out during the latter half of February 2012 on 50 students chosen randomly from the Faculty of Medicine. The required modifications were done. The results of the pilot study were not included in this work.

\section{Ethical considerations}

A written informed consent (in Arabic language) was obtained from all students before participation; this included data about the aims, design, site, timing, subjects and tools of the study. They were informed that all collected data would be confidential and used only for scientific purposes. They were informed also that no invasive or painful techniques would be involved. Approval was obtained from the research ethics committee in University of Benha Faculty of Medicine and from the dean of the faculties and the vicepresident for education affairs of the University.

\section{Statistical analysis}

The collected data were tabulated and analysed using SPSS, version 16 software. Qualitative data were expressed as frequencies and percentages, while quantitative variables were presented as mean and standard deviation (SD). Chi-squared or Fisher exact tests were used as tests of significance. Odds ratios (OR) and the corresponding 95\% confidence intervals (CI) were calculated. Binary logistic regression analysis (logit model, enter method) was used to detect the significant predictors of road-risky behaviours. A 2-sided $P$-value $<0.05$ was considered significant.

\section{Results}

\section{Sociodemographic characteristics of the studied students}

The mean age of the 953 respondents was 20.3 (SD 1.4) years and $25.8 \%$ were aged $<20$ years; $62.1 \%$ were females, $57.6 \%$ were from rural areas and $61.7 \%$ of them studied in the medical or science colleges. Junior students constituted $35.6 \%$ of the sample while $64.4 \%$ were seniors. The great majority of the students $(93.6 \%)$ were living with their families and $50.6 \%$ of them reported having a "bad" relationship with their parents. On the other hand, $97.1 \%$ of them had "good" relationships with their friends and $47.7 \%$ had a religious commitment (Table 1).

\section{Road-risk behaviours among the studied students}

The responses revealed that $19.3 \%$ of the surveyed students did not follow the pedestrian road traffic safety rules (i.e. they neglected 1 or more of the 4 rules). The great majority of them (94.8\%) reported that they did not use alcohol or other substances. The results also showed that $26.7 \%$ of the studied

\begin{tabular}{|c|c|c|}
\hline Sociodemographic characteristics & No. & $\%$ \\
\hline \multicolumn{3}{|l|}{ Age (years) } \\
\hline$<20$ & 246 & 25.8 \\
\hline$\geq 20$ & 707 & 74.2 \\
\hline \multicolumn{3}{|l|}{ Sex } \\
\hline Male & 361 & 37.9 \\
\hline Female & 592 & 62.1 \\
\hline \multicolumn{3}{|l|}{ College type } \\
\hline Commerce & 365 & 38.3 \\
\hline Medical/Science & 588 & 61.7 \\
\hline \multicolumn{3}{|l|}{ Grade } \\
\hline Junior $^{\mathrm{a}}$ & 339 & 35.6 \\
\hline Senior & 614 & 64.4 \\
\hline \multicolumn{3}{|l|}{ Residence } \\
\hline Rural & 549 & 57.6 \\
\hline Urban & 404 & 42.4 \\
\hline \multicolumn{3}{|l|}{ Place of living } \\
\hline With family & 892 & 93.6 \\
\hline Away from family ${ }^{b}$ & 61 & 6.4 \\
\hline \multicolumn{3}{|l|}{ Student-parent relationship } \\
\hline Good & 471 & 49.4 \\
\hline Bad & 482 & 50.6 \\
\hline \multicolumn{3}{|l|}{ Relationship with friends } \\
\hline Good & 922 & 97.1 \\
\hline Bad & 28 & 2.9 \\
\hline \multicolumn{3}{|l|}{ Religious commitment } \\
\hline Yes & 455 & 47.7 \\
\hline No & 498 & 52.3 \\
\hline
\end{tabular}

aJuniors: years 1-3; ${ }^{b}$ Student hostel, living with friends, private flat. 


\begin{tabular}{|c|c|c|}
\hline \multicolumn{3}{|c|}{$\begin{array}{l}\text { Table } 2 \text { Frequency distribution of the studied students according to their self- } \\
\text { reported risky behaviours concerning road use when they were pedestrians and } \\
\text { when driving a vehicle }\end{array}$} \\
\hline Variable & No. & $\%$ \\
\hline \multicolumn{3}{|c|}{ All respondents $(n=953)$} \\
\hline \multicolumn{3}{|c|}{ Non-compliant with pedestrian road safety rules ${ }^{a}$} \\
\hline Yes & 184 & 19.3 \\
\hline No & 769 & 80.7 \\
\hline \multicolumn{3}{|c|}{ Substance use } \\
\hline Alcohol & 5 & 0.5 \\
\hline Other ${ }^{b}$ & 45 & 4.7 \\
\hline None & 903 & 94.8 \\
\hline \multicolumn{3}{|c|}{ Drivers $(n=137)$} \\
\hline \multicolumn{3}{|c|}{ Have driving licence } \\
\hline Yes & 83 & 60.6 \\
\hline No & 54 & 39.4 \\
\hline \multicolumn{3}{|c|}{ Use seat-belt } \\
\hline Yes & 76 & 55.5 \\
\hline No & 61 & 44.5 \\
\hline \multicolumn{3}{|c|}{ Obey speed limits } \\
\hline Yes & 50 & 36.5 \\
\hline No & 87 & 63.5 \\
\hline \multicolumn{3}{|c|}{ Substance use when driving } \\
\hline Alcohol & 4 & 2.9 \\
\hline Other ${ }^{b}$ & 26 & 19.0 \\
\hline None & 107 & 78.1 \\
\hline
\end{tabular}

${ }^{a}$ Non-compliance with any of the 4 rules: always looking both ways before crossing the street; always waiting for green signal to cross; never walking in the road; or never walking in the sidewalk; ${ }^{\circ}$ Marijuana, hashish.

students had been exposed to road injury in the previous 6 months.

A total of 137 students (14.4\%) were drivers (either car owners or not); 54 of them (39.4\%) reported having no driving licence, 61 (44.5\%) did not use a seat-belt while driving, 87 (63.5\%) admitted that they did not obey the traffic speed limits and $2.9 \%$ of them used alcohol when driving (Table 2).

\section{Factors affecting road-risk behaviours among the studied students}

When we analysed the factors associated with not following pedestrian road safety rules we found a significant relationship with age, peer-group behaviour, substance use and family influences $(P<0.05)$. Students who did not follow traffic rules were more likely to be $\geq 20$ years old, have friends with similar behaviour, be substance users and to live away from their family (ORs 1.07, 2.8, 33.2 and 1.83 respectively) (Table 3). After binary logistic regression, however, peers with similar behaviours (OR 2.53 ; 96\% CI: $1.15-5.55 ; P=0.021)$ and substance use (OR 18.3 95\% CI: $9.10-23.3 ; P<0.001)$ were the only significant predictors of not following the pedestrian traffic safety rules (Table 4).

Analysing road safety precautions among the subset of students who drove a car we found that there was no significant association of reported seatbelt use with age, sex, residence, college, grade, place of living, relationship with parents, peer-group behaviour, religious commitment or substance use (all $P$ $>0.05$ ) (Table 5). However, among students who reported exceeding the speed limit there was a significant association with male sex, peer pressure and substance use (all $P<0.05)$ (Table $6)$. Students who exceeded the speed limits when driving were more likely to be males, have peers with similar behaviours and be substance users. In binary logistic regression analysis male sex (OR 5.13; 95\% CI: 1.98-13.3; P $<0.001$ ), peer-group behaviour (OR 8.70; 95\% CI: 3.90-17.1; $P<0.001)$ and substance use (OR 3.30; 95\% CI: $1.58-13.7 ; P=0.01)$ remained as significant predictors of exceeding the speed limit (Table 7).

\section{Discussion}

Young people have specific health and development needs and face many challenges that hinder their well-being (3). The current study identified some risky behaviours concerning road use among the studied university students; $19.3 \%$ of them had at least 1 of the 4 risky behaviours related to pedestrian road use rules (not always looking both ways before crossing the street, not always waiting for green signal to cross, ever walking in the road and ever walking in the sidewalk). Similar findings were reported in a cross-sectional study of health-risk behaviour related to road safety among adolescent students in south Delhi which found that $29.8 \%$ of the studied students always/mostly/ sometimes disobeyed traffic rules (12).

This study revealed that $26.7 \%$ of the studied students had been exposed to road injury in the past 6 months. This agrees with Ibrahim et al., who conducted a cross-sectional survey among Ain Shams University students in Cairo, Egypt, to study the risk perception and pedestrian injuries. They found that $21.9 \%$ of the participants had suffered from a pedestrian injury and that inappropriate road behaviours by youths were significantly associated with pedestrian traffic injuries (4).

This study demonstrated that $5.2 \%$ of the students reported using 


\begin{tabular}{|c|c|c|c|c|c|c|}
\hline \multirow[t]{3}{*}{ Sociodemographic characteristics } & \multicolumn{4}{|c|}{ Non-compliant with road safety rules ${ }^{a}$} & \multirow[t]{3}{*}{$P$-value } & \multirow[t]{3}{*}{ OR $(95 \% \mathrm{Cl})$} \\
\hline & \multicolumn{2}{|c|}{$\begin{array}{c}\text { Yes } \\
(n=184)\end{array}$} & \multicolumn{2}{|c|}{$\begin{array}{c}\text { No } \\
(n=769)\end{array}$} & & \\
\hline & No. & $\%$ & No. & $\%$ & & \\
\hline \multicolumn{7}{|l|}{ Age (years) } \\
\hline$<20$ & 37 & 20.1 & 209 & 27.2 & \multirow{2}{*}{0.049} & \multirow{2}{*}{$1.48(1.00-2.19)$} \\
\hline$\geq 20$ (ref.) & 147 & 79.9 & 560 & 72.8 & & \\
\hline \multicolumn{7}{|l|}{ Sex } \\
\hline Male & 80 & 43.5 & 281 & 36.5 & \multirow{2}{*}{0.081} & \multirow{2}{*}{$0.75(0.54-1.04)$} \\
\hline Female (ref.) & 104 & 56.5 & 488 & 63.5 & & \\
\hline \multicolumn{7}{|l|}{ Residence } \\
\hline Rural & 103 & 56.0 & 446 & 58.0 & \multirow{2}{*}{0.619} & \multirow{2}{*}{$1.08(0.79-1.50)$} \\
\hline Urban (ref.) & 81 & 44.0 & 323 & 42.0 & & \\
\hline \multicolumn{7}{|l|}{ College type } \\
\hline Commerce & 79 & 42.9 & 286 & 37.2 & \multirow{2}{*}{0.150} & \multirow{2}{*}{$0.79(0.57-1.09)$} \\
\hline Medical/Science (ref.) & 105 & 57.1 & 483 & 62.8 & & \\
\hline \multicolumn{7}{|l|}{ Grade } \\
\hline Junior & 68 & 37.0 & 271 & 35.2 & \multirow{2}{*}{0.662} & \multirow{2}{*}{$1.08(0.77-1.50)$} \\
\hline Senior (ref.) & 116 & 63.0 & 498 & 64.8 & & \\
\hline \multicolumn{7}{|l|}{ Place of living } \\
\hline With family & 166 & 92.2 & 726 & 94.4 & \multirow{2}{*}{0.039} & \multirow{2}{*}{$1.83(1.03-3.26)$} \\
\hline Away from family (ref.) & 18 & 7.8 & 43 & 5.6 & & \\
\hline \multicolumn{7}{|l|}{ Student-parent relationship } \\
\hline Bad (ref.) & 98 & 53.3 & 384 & 49.9 & \multirow{2}{*}{0.418} & \multirow{2}{*}{$1.14(0.83-1.58)$} \\
\hline Good & 86 & 46.7 & 385 & 50.1 & & \\
\hline \multicolumn{7}{|l|}{ Peers always disobey traffic rules } \\
\hline Yes (ref.) & 11 & 6.0 & 17 & 2.2 & \multirow{2}{*}{0.007} & $280(129-609)$ \\
\hline No & 173 & 94.0 & 752 & 97.8 & & $2.00(1.250 .03$ \\
\hline Religious commitment & & & & & & \\
\hline Yes & 85 & 46.2 & 370 & 48.1 & 0640 & 108(0-78-149) \\
\hline No (ref.) & 99 & 53.8 & 399 & 51.9 & 0.040 & $1.00(0.70-1.45)$ \\
\hline Substance use & & & & & & \\
\hline Yes (ref.) & 43 & 23.4 & 7 & 0.9 & & $332(146-753)$ \\
\hline No & 141 & 76.6 & 762 & 91.1 & 0.00 & \\
\hline
\end{tabular}

${ }^{a}$ Non-compliance with any of the 4 rules: always looking both ways before crossing the street; always waiting for green signal to cross; never walking in the road; or never walking in the sidewalk.

$($ ref. $)=$ reference category.

$\mathrm{OR}=$ odds ratio; $\mathrm{Cl}=$ Confidence interval

alcohol and other substances. This is a States (US) in 2011 were considerably low figure, but is similar to that reported higher; $38.7 \%$ of students nationwide in Egypt in 2005 by Abd El Rahim, had had at least one drink of alcohol whereby a minority of the student population drank alcohol (5.4\%) and used marijuana (3.1\%) (9). On the other hand, the reported rates published by the Youth Health Risk Behaviour Surveillance Survey in the United the cultural, social and religious differences between the societies. Despite the relatively small number of users in our study, alcohol use was found to be significantly associated with and a significant predictor of violation of pedestrian road safety rules and exceeding the legal speed when driving. This variable was also found to be directly 


\begin{tabular}{|c|c|c|}
\hline Variable & $\begin{array}{l}\text { Non-compliant with road safety rules } \\
\text { OR }(95 \% \mathrm{CI})\end{array}$ & $P$-value \\
\hline Age ( $\geq 20$ years $)$ & $1.13(0.99-1.29)$ & 0.061 \\
\hline Sex (female) & $0.76(0.54-1.08)$ & 0.126 \\
\hline Residence (urban) & $1.22(0.80-1.57)$ & 0.497 \\
\hline College type (practical) & $0.83(0.58-1.19)$ & 0.312 \\
\hline Grade (senior) & $0.75(0.51-1.10)$ & 0.137 \\
\hline Relationship with parents (bad) & $1.02(0.98-1.48)$ & 0.081 \\
\hline Place of living (with family) & $0.94(0.67-1.32)$ & 0.726 \\
\hline Peers always disobey traffic rules (yes) & $2.53(1.15-5.55)$ & 0.021 \\
\hline Religious commitment (no) & $1.15(0.81-1.61)$ & 0.433 \\
\hline Substance use (yes) & $18.3(9.10-23.3)$ & $<0.001$ \\
\hline
\end{tabular}

${ }^{a}$ Non-compliance with any of the 4 rules: always looking both ways before crossing the street; always waiting for green signal to cross; never walking in the road; never walking on the sidewalk.

$O R=$ odds ratio; $C l=$ confidence interval.

Table 5 Sociodemographic characteristics of students according to self-reported risky behaviour in not wearing a seat-belt when driving (drivers only, $n=137$ )

\begin{tabular}{|c|c|c|c|c|c|c|}
\hline \multirow[t]{3}{*}{ Sociodemographic characteristics } & \multicolumn{4}{|c|}{ Not wearing seat-belt } & \multirow[t]{3}{*}{$P$-value } & \multirow[t]{3}{*}{ OR $(95 \% \mathrm{CI})$} \\
\hline & \multicolumn{2}{|c|}{ Yes $(n=61)$} & \multicolumn{2}{|c|}{ No $(n=76)$} & & \\
\hline & No. & $\%$ & No & $\%$ & & \\
\hline \multicolumn{7}{|l|}{ Age (years) } \\
\hline$<20$ (ref.) & 11 & 18.0 & 13 & 17.1 & \multirow{2}{*}{0.887} & \multirow{2}{*}{$1.07(0.44-2.58)$} \\
\hline$\geq 20$ & 50 & 82.0 & 63 & 82.9 & & \\
\hline \multicolumn{7}{|l|}{ Sex } \\
\hline Male & 45 & 73.8 & 58 & 76.3 & \multirow{2}{*}{0.732} & \multirow{2}{*}{$1.15(0.53-2.49)$} \\
\hline Female (ref.) & 16 & 26.2 & 18 & 23.7 & & \\
\hline \multicolumn{7}{|l|}{ Residence } \\
\hline Rural & 25 & 41.0 & 32 & 42.1 & \multirow{2}{*}{0.895} & \multirow{2}{*}{$0.96(0.48-1.89)$} \\
\hline Urban (ref.) & 36 & 59.0 & 44 & 57.9 & & \\
\hline \multicolumn{7}{|l|}{ College type } \\
\hline Commerce & 23 & 37.7 & 35 & 46.1 & \multirow{2}{*}{0.326} & \multirow{2}{*}{$1.41(0.71-2.80)$} \\
\hline Medical/Science (ref.) & 38 & 62.3 & 41 & 53.9 & & \\
\hline \multicolumn{7}{|l|}{ Grade } \\
\hline Junior (ref.) & 24 & 39.3 & 28 & 36.8 & \multirow{2}{*}{0.764} & \multirow{2}{*}{$1.11(0.56-2.23)$} \\
\hline Senior & 37 & 60.7 & 48 & 63.2 & & \\
\hline \multicolumn{7}{|l|}{ Place of living } \\
\hline With family & 56 & 91.8 & 70 & 92.1 & \multirow{2}{*}{0.95} & \multirow{2}{*}{$1.04(0.30-3.59)$} \\
\hline Away from family (ref.) & 5 & 8.2 & 6 & 7.9 & & \\
\hline \multicolumn{7}{|l|}{ Student-parent relationship } \\
\hline Good & 29 & 47.5 & 39 & 51.3 & \multirow{2}{*}{0.66} & \multirow{2}{*}{$1.16(0.59-2.28)$} \\
\hline Bad (ref.) & 32 & 52.5 & 37 & 48.7 & & \\
\hline \multicolumn{7}{|l|}{ Peers neglect seat-belt use } \\
\hline Yes (ref.) & 53 & 86.9 & 65 & 85.3 & \multirow{2}{*}{0.82} & \\
\hline No & 8 & 13.1 & 11 & 14.5 & & $1.12(0.42-2.99)$ \\
\hline Religious commitment & & & & & & \\
\hline Yes (ref.) & 32 & 52.5 & 33 & 43.4 & 029 & $1.44(0.73-2.83)$ \\
\hline No & 29 & 47.5 & 43 & 56.6 & 0.29 & $1.44(0 . / 3-2.83)$ \\
\hline Substance use & & & & & & \\
\hline Yes (ref.) & 18 & 29.5 & 12 & 15.8 & & \\
\hline No & 43 & 70.5 & 64 & 84.2 & 0.057 & $2.23(0.98-5.10)$ \\
\hline
\end{tabular}

$($ ref. $)=$ reference group; $O R=$ odds ratio; $C l=$ confidence interval. 
implicated in road traffic accidents in India (12).

This study showed that among the $14.4 \%$ of students who were car drivers, $39.4 \%$ admitted to not having a driving licence, $44.5 \%$ to not using a seat-belt and $63.5 \%$ to not always obeying the speed limits on the roads. Although we did not investigate students' socioeconomic status, this finding could reflect the effect of social class on road-risk behaviours, as those who drove a car were mostly car owners and were likely to be of a higher socioeconomic status.
The percentage of student drivers who reported that they did not use seat-belts in this study was high in comparison with the results obtained by the National College Health Risk Behaviour Survey in the US performed on 4609 undergraduate college students from public and private universities in 2003, in which only $10.2 \%$ did not use a seat-belt when driving (14). This difference could be due to differences in culturally determined attitudes to risk-taking between the countries and also to the lack of application of existing traffic laws in Egypt.
The present study showed that sex was not an important factor in neglecting to use a seat-belt. This was clear in a study performed on private university students in Egypt which showed that the percentage of male students who did not use a seat-belt was comparable to that of female students (9). This could be explained by the lack of strict application of legislation in Egypt to prevent these risky behaviours.

The current study showed that there was no significant difference in the percentage of students in commerce- or

\begin{tabular}{|c|c|c|c|c|c|c|}
\hline \multicolumn{7}{|c|}{$\begin{array}{l}\text { Table } 6 \text { Sociodemographic characteristics of students according to self-reported risky behaviour in exceeding traffic speed } \\
\text { limits when driving (drivers only, } n=137 \text { ) }\end{array}$} \\
\hline \multirow[t]{3}{*}{ Demographic characteristics } & \multicolumn{4}{|c|}{ Exceeding traffic speed limits } & \multirow[t]{3}{*}{$P$-value } & \multirow[t]{3}{*}{ OR $(95 \% \mathrm{Cl})$} \\
\hline & \multicolumn{2}{|c|}{ Yes $(n=87)$} & \multicolumn{2}{|c|}{ No $(n=50)$} & & \\
\hline & No. & $\%$ & No. & $\%$ & & \\
\hline \multicolumn{7}{|l|}{ Age (years) } \\
\hline$<20$ & 12 & 13.8 & 12 & 24.0 & \multirow{2}{*}{0.13} & \multirow{2}{*}{$1.97(0.81-4.80)$} \\
\hline$\geq 20$ (ref.) & 75 & 86.2 & 38 & 76.0 & & \\
\hline \multicolumn{7}{|l|}{ Sex } \\
\hline Male (ref.) & 75 & 86.2 & 28 & 56.0 & \multirow{2}{*}{$<0.001$} & \multirow{2}{*}{$4.90(2.15-11.2)$} \\
\hline Female & 12 & 13.8 & 22 & 44.0 & & \\
\hline \multicolumn{7}{|l|}{ Residence } \\
\hline Rural (ref.) & 36 & 41.4 & 21 & 42.0 & \multirow{2}{*}{0.943} & \multirow{2}{*}{$0.98(0.48-1.97)$} \\
\hline Urban & 51 & 58.6 & 29 & 58.0 & & \\
\hline \multicolumn{7}{|l|}{ College type } \\
\hline Theoretical & 33 & 37.9 & 25 & 50.0 & \multirow{2}{*}{0.169} & \multirow{2}{*}{$1.64(0.81-3.30)$} \\
\hline Practical (ref.) & 54 & 62.1 & 25 & 50.0 & & \\
\hline \multicolumn{7}{|l|}{ Grade } \\
\hline Junior (ref.) & 32 & 36.8 & 20 & 40.0 & \multirow{2}{*}{0.709} & \multirow{2}{*}{$0.87(0.43-1.78)$} \\
\hline Senior & 55 & 63.2 & 30 & 60.0 & & \\
\hline \multicolumn{7}{|l|}{ Place of living } \\
\hline With family & 77 & 88.5 & 49 & 98.0 & \multirow{2}{*}{0.082} & \multirow{2}{*}{$6.36(0.79-51.3)$} \\
\hline Away from family (ref.) & 10 & 11.5 & 1 & 2.0 & & \\
\hline \multicolumn{7}{|l|}{ Student-parent relationship } \\
\hline Good & 44 & 50.6 & 24 & 48.0 & \multirow{2}{*}{0.772} & \multirow{2}{*}{$0.90(0.45-1.81)$} \\
\hline Bad (ref.) & 43 & 49.4 & 26 & 52.0 & & \\
\hline \multicolumn{7}{|l|}{ Peers exceed speed limits } \\
\hline Yes (ref.) & 73 & 83.9 & 17 & 34.0 & $<0,001$ & $101(447-229)$ \\
\hline No & 14 & 16.1 & 33 & 66.0 & $<0.001$ & $10.1(4.47-22.9)$ \\
\hline Religious commitment & & & & & & \\
\hline Yes & 48 & 55.2 & 20 & 40.0 & 0087 & (54) 54 (0) \\
\hline No (ref.) & 39 & 44.8 & 30 & 60.0 & 0.007 & (1.10) \\
\hline Substance use & & & & & & \\
\hline Yes (ref.) & 26 & 29.9 & 4 & 8.0 & 0005 & $490(160-150)$ \\
\hline No & 61 & 70.1 & 46 & 92.0 & 0.005 & \\
\hline
\end{tabular}

(ref. $)=$ reference group; $O R=$ odds ratio $; C l=$ confidence interval . 


\begin{tabular}{|c|c|c|}
\hline \multirow[t]{2}{*}{ Variable } & \multicolumn{2}{|c|}{ Exceeding traffic speed limits } \\
\hline & OR $(95 \% \mathrm{CI})$ & $P$-value \\
\hline Age $(\geq 20$ years $)$ & $1.17(0.82-1.76)$ & 0.39 \\
\hline Sex (male) & $5.13(1.98-13.3)$ & 0.001 \\
\hline Residence (urban) & $1.24(0.53-2.90)$ & 0.618 \\
\hline College (practical) & $2.28(0.99-5.26)$ & 0.053 \\
\hline Grade (junior) & $0.73(0.25-2.17)$ & 0.576 \\
\hline Place of living (away from family) & $1.47(0.63-3.41)$ & 0.371 \\
\hline Relationship with parent (bad) & $0.54(0.27-1.08)$ & 0.082 \\
\hline Peers exceed speed limits (yes) & $8.70(3.90-17.1)$ & $<0.001$ \\
\hline Religious (yes) & $1.17(0.51-2.69)$ & 0.713 \\
\hline Substance use (yes) & $3.30(1.58-13.7)$ & 0.01 \\
\hline
\end{tabular}

$O R=$ odds ratio; $C I=$ confidence interval.

medical/science colleges who did not use seat-belts when driving. This is in accordance with a study of Egyptian students, in which the percentages of students with practical or theoretical fields of study were similar in terms of seat-belt use (9).

Numerous studies have shown that peer pressure has a significant effect on risky behaviours during adolescence. Our study showed that students who did not follow pedestrian road safety rules were nearly 3 times more likely to have friends with similar behaviour (OR 2.80). Peer-group behaviour was also a highly significant factor associated with drivers not obeying the traffic speed limits. This is in accordance with Allen and Brown, who examined a range of developmental and structural factors that potentially increase the risks associated with adolescent driving. They stated that motor vehicle crash rates and fatality rates rise dramatically when teen drivers are accompanied by peer passengers (15). These findings underscore the need to pay closer attention to the ways in which peers influence teen driving behaviour.

The findings of this study were subject to some limitations. First, the data were collected only from youth who attended university and therefore were not representative of all persons in this age group (although this did not impact our objective which was to study university students). Secondly, there may have been misreporting of responses, as the questionnaires were applied under observation during classes. This may have meant that some students did not respond truthfully, especially to the questions on alcohol and drug use. Nevertheless, our results are broadly consistent with the literature.

\section{Conclusions and} Recommendations

Unsafe road-use behaviours that may cause unintentional injuries, such as not following pedestrian road safety rules, non-compliance with seat-belt laws and exceeding the legal speed limit when driving were prevalent among University of Benha students.

A behavioural approach through health education sessions and training courses on appropriate road behaviours could be arranged in the universities. Furthermore, stricter application of the existing legislation in Egypt would help to reduce risky behaviours such as driving without a licence, neglecting seatbelt use or driving under the influence of alcohol.

\section{Funding: None.}

Competing interests: None declared.

\section{References}

1. Assaad R, Roudi-Fahimi F. Youth in the Middle East and North Africa: demographic opportunity or challenge? Washington (DC): Population Reference Bureau; 2007 (http://www.prb. org/pdf07/youthinmena.pdf, accessed 11 December 2014).

2. De Guzman MR, Pohlmeier LA. High-risk behaviors among youth. Lincoln (NE): University of Nebraska-Lincoln Extension, Institute of Agriculture and Natural Resources; 2007 (http://www.ianrpubs.unl.edu/pages/publicationD. jsp?publicationld=786, accessed 11 December 2014).

3. Adolescents: health risks and solutions. Fact sheet No. 345. Geneva: World Health Organization; 2011 (http://www. who.int/mediacentre/factsheets/fs345/en/, accessed 11 December 2014).

4. Ibrahim JM, Day H, Hirshon JM, El-Setouhy M. Road riskperception and pedestrian injuries among students at Ain Shams University, Cairo, Egypt. J Inj Violence Res. 2012 Jul;4(2):65-72. PMID: 21502783

5. Bicyclists and other cyclists. Traffic safety facts: 2007 data. Washington (DC): National Highway Traffic Safety Administration, National Center for Statistics and Analysis; 2007 (http://www-nrd.nhtsa.dot.gov/Pubs/810986.pdf, accessed 11 December 2014). 
6. Trond N, Torbjorn R. Perceptions of traffic risk in an industrialized and a developing country. Transp Res, Part F Traffic Psychol Behav. 2009 Jan;12(1):91-8.

7. Seif El-Din A. Surveillance system for road traffic accidents in Cairo, Egypt [MD thesis]. Cairo: Department of Public Health, Faculty of Medicine, University of Cairo; 2006.

8. Eaton DK, Kann L, Kinchen S, Shanklin S, Ross J, Hawkins J, et al: Youth risk behavior surveillance. United States-2009. MMWR Surveill Summ. 2010 Jun 4;59(5):1-142. PMID:20520591

9. Abd EL-Rahim I. Health risk behaviors among students of private universities in Egypt [MSc thesis]. Cairo: Faculty of Medicine, Ain Shams University; 2005.

10. Abd Allah H. Study of health risk behaviors among scientific professionals [MSc thesis]. Cairo: Faculty of Medicine, Ain Shams University; 2003.

11. Wade MV. Likert-type scale response anchors. Clemson (SC): Clemson International Institute for Tourism and Research
Development, Department of Parks, Recreation and Tourism Management; 2006.

12. Sharma R, Grover VL, Chaturvedi S. Health-risk behaviors related to road safety among adolescent students. Indian J Med Sci. 2007 Dec;61(12):656-62. PMID: 18174635

13. Eaton DK, Kann L, Kinchen S, Shanklin S, Flint KH, Hawkins J, et al. Youth risk behavior surveillance-United States, 2011. MMWR Surveill Summ. 2012 Jun 8;61(4):1-162. PMID: 22673000

14. Centers for Disease Control and Prevention (CDC). Health risk behaviors among adolescents who do and do not attend school-United States, 1992. MMWR Morb Mortal Wkly Rep. 1994 Mar 4;43(8):129-32. PMID:8309460

15. Allen JP, Brown BB. Adolescents, peers, and motorvehicles: the perfect storm? Am J Prev Med. Sep 2008; 35(3 Suppl): S289-93. 